Original Article

\title{
Changes in Some Inflammatory Indices in Men with Heart Failure after Eight Weeks of Continuous and Intermittent Aerobic Exercise
}

Seyed Mahmoud Hejazi

(PhD) Department of Physical

Education, Khayyam University,

Mashhad, Iran

Ladan Hosseni Abrishami

(PhD) Department of Physical

Education, Khayyam University,

Mashhad, Iran

Corresponding author: Ladan

Hosseni Abrishami

Email: ladan.abrishami@gmail.com

Tel: 989153597187

Address:Department of Physical Education, Khayyam University, Imam Ali Highway, Mashhad, Iran

Received: $2019 / 08 / 17$

Revised: 2019/11/8

Accepted: 2019/12/11

This work is licensed under a Creative

Commons Attribution 4.0 License.

\section{(i) (8)}

DOI: $10.29252 / \mathrm{mlj} .14 .5 .42$

\begin{abstract}
Background and objectives: Evidence has shown that inflammatory mediators play an important role in the pathogenesis of atherosclerosis. The aim of this study was to evaluate effects of eight weeks of continuous and intermittent aerobic exercise on some inflammatory indices in men with heart failure.
\end{abstract}

Methods: The effects of continuous aerobic exercise (at 45-70\% maximum heart rate) and intermittent aerobic exercise (at 45$80 \%$ of maximum heart rate) on the level of interleukin 6 (IL-6) and high-sensitivity C-reactive protein (hs-CRP) and tumor necrosis factor alpha (TNFa) were evaluated in 42 men with heart failure using commercial ELISA kits. Blood samples were taken after 12 hours of fasting one hour before the first session and 48 hours after the last exercise session. The subjects performed exercises three sessions a week, for eight weeks. Data were analyzed by one-way ANOVA at significance of 0.05 .

Results: After the exercise program, serum hs-CRP $(\mathrm{P}=0.023)$, IL-6 $(\mathrm{P}=0.018)$ and TNF- $\alpha \quad(\mathrm{P}=0.048)$ differed significantly between the exercise groups and the control group. In addition, serum levels of IL-6 and hs-CRP decreased slightly in the intermittent aerobic group, but there was no significant difference between the two exercise groups. Intermittent aerobic exercise significantly reduced serum TNF- $\alpha$ level compared to the control group.

Conclusion: Probably aerobic exercise can have positive effects on the level of hs-CRP, IL-6 and TNF- $\alpha$ in patients with heart failure.

Keywords: IL-6, hs-CRP, TNF- $\alpha$, Aerobic Exercise, Heart Failure. 


\section{INTRODUCTION}

Chronic inflammation plays a main role in the development and progression of atherosclerosis $(1,2)$ through endothelial activation and expression of adhesion molecules on the surface of activated endothelial cells (3). Excessive and chronic production of inflammatory cytokines disrupts cardiac contraction and may induce hypertrophy and apoptosis of cardiomyocytes. Therefore, these inflammatory cytokines can be considered as important markers of severity and progression of cardiovascular disease and heart failure.

Tumor necrosis factor (TNF) is a cytokine produced by macrophages and neutrophils that has several potent pro-inflammatory effects. It mediates host responses in chronic/acute inflammatory conditions and plays an important role in the pathogenesis and progression of atherosclerosis and heart failure $(4,5)$. Interleukin-6 (IL-6) is produced and released by mononuclear phagocytes, vascular endothelial cells, fibroblasts and some other cells in response to microbes and certain cytokines, especially IL-1 and TNF- $\alpha$, which are mainly present in monocytes and macrophages. It is considered one of the most important mediators in development of inflammation symptoms in the human body (6). Reports suggest that the activation of inflammatory markers such as IL-6, TNF- $\alpha$ and high sensitivity C-reactive protein (hsCRP) during cardiovascular disease play a role in the migration of inflammatory cells to the sub-endothelial layer of vessels through activation of cellular factors produced by cytokines (7). In this regard, Tsimikas et al. introduced IL-6 and some pro-inflammatory indices as risk factors of heart failure (8). In addition, hsCRP can predict the risk of coronary events and cardiovascular disease among healthy people (9). This protein is secreted in response to IL-6 and IL-1 $\beta$ inflammatory cytokines and contributes to the progression of arteriosclerosis through ICAM1 and monocyte chemotactic protein- 1 . In this context, Signorelli et al. studied the changes in cytokines of patients with peripheral arterial disease. The results showed that the levels of anti-inflammatory markers increased significantly in patients and the control group after treadmill running (10). Michowitz et al. reported that hs-CRP is raised in patients with heart failure and may predict severity of the disease (11).

The program was set up individually and
Most findings from studies suggested that after regular aerobic exercise, inflammatory responses are restrained due to a decrease in the predictive indicators of cardiovascular disease $(12,13)$. According to studies, aerobic exercise has evident positive effects on the level of inflammatory markers including VCAM-1, IL-6, CRP and TNF- $\alpha$ in patients with heart failure (14). It has also been reported that the risk of cardiovascular disease is significantly lower in people who get more weekly exercise (15). Moreover, a number of studies suggested that most people rather participate in intermittent exercise, which can significantly reduce inflammatory markers $(16,17)$.

The aim of this study was to investigate effects of eight weeks of continuous and intermittent aerobic exercise on some inflammatory indices in men with heart failure.

\section{MATERIALS AND METHODS}

This was a semi-experimental research with a pretest posttest design. Study population included 42 men aged 50-60 years old with confirmed heart failure (grade 1 to 3 ) and ejection fraction of less than $45 \%$ (inclusion criteria) who were enrolled via purposeful sampling. The subjects were randomly and equally divided into three groups of continuous aerobic exercise, intermittent aerobic exercise and control. This study was approved by the Iranian Center for Clinical Trials (IRCT20180721040545N1) and the Ethics Committee of the Research Institute of Sport Sciences (IR.SSRI.REC.1397.214).

Exclusion criteria included having a history of heart disease for less than 5 years and regular exercise in the past six months. In the first session, age, height, weight and body mass index (BMI) of the subjects were recorded. Weight was measured using a Seca scale with minimal clothing. The height of subjects was measured with no shoe using a Seca altimeter with a precision of $0.1 \mathrm{~cm}$. The subjects exercised under supervision of a cardiologist, three sessions a week, for eight weeks, and their vitals were monitored by a nurse.Level of IL- 6 and TNF- $\alpha$ was determined using a commercial ELISA kit (Bender Med System, Austria). Serum level of IL-6 (sensitivity: 0.92 $\mathrm{pg} / \mathrm{ml}$, inter-assay coefficient of variation: $5.2 \%$ and intra-assay coefficient of variation: $3.4 \%$ ), serum level of TNF- $\alpha$ (sensitivity:0.5pg/ml, inter- assay coefficient of variation: $8.1 \%$ and intra-assay coefficient 
of variation: $7.7 \%$ ) and serum level of hs-CRP was measured using an ELISA Reader (TECAN IBL International, Germany), with a sensitivity of $<1 \mathrm{mg} / \mathrm{ml}$, inter-assay of $4.3 \%$ and intra-assay coefficient of variation of $5.2 \%$. To measure biochemical parameters, blood samples were taken after 12 hours of fasting one hour before the first the exercise session and 48 hours after the last exercise session. The subjects were advised not to perform intense physical activity within 24 hours of sampling. An experiment was performed 48 hours after the last exercise session with the same pre-test conditions in order to reduce fatigue interference. After centrifugation, serum of each subject was stored at $-80^{\circ} \mathrm{C}$ until analysis.

The exercise program was performed using treadmill with ergometer to determine the heart rate and training intensity. Based on the primary ability of each subject, the exercise program was performed after the stress test. purposefully to increase functional capacity based on the principles of practice design and according to the recommendations of the American College of Sports Medicine (ACSM). The exercise program was also designed under the supervision of a medical specialist. The subjects performed continuous exercise (at 45$70 \%$ maximum heart rate) and intermittent exercise (at $45-80 \%$ of maximum heart rate), with 10-minutes warm up, 5-10 minutes rest between each set and cool down by stretching exercises (Table 1) (18). After confirming normal distribution of data by the Shapiro-Wilk test and ensuring the homogeneity of variances by the Levene's test, inter-group differences were analyzed using one-way analysis of variance (ANOVA) and Tukey's post hoc test. All statistical analyses were performed in SPSS software (version 16) at significance of 0.05 .

Table 1. Details of the exercise protocol

\begin{tabular}{|c|c|c|c|c|c|c|c|c|c|c|}
\hline Exercise & Vehicle & Variable & $\begin{array}{c}\text { Week } \\
1\end{array}$ & $\begin{array}{c}\text { Week } \\
2\end{array}$ & $\begin{array}{c}\text { Week } \\
3\end{array}$ & $\begin{array}{c}\text { Week } \\
4\end{array}$ & $\begin{array}{c}\text { Week } \\
5\end{array}$ & $\begin{array}{c}\text { Week } \\
6\end{array}$ & $\begin{array}{c}\text { Week } \\
7\end{array}$ & $\begin{array}{l}\text { Wee } \\
\text { k } 8\end{array}$ \\
\hline \multirow[t]{2}{*}{$\begin{array}{c}\text { Continuous } \\
\text { aerobic }\end{array}$} & $\begin{array}{l}\text { Treadmill } \\
\text { running }\end{array}$ & $\begin{array}{c}\text { Intensity } \\
(\% \\
\text { MHR })\end{array}$ & $45-50$ & $50-55$ & $55-60$ & $55-60$ & $60-65$ & $60-65$ & $65-70$ & $65-70$ \\
\hline & & $\begin{array}{c}\text { Duration } \\
\text { (min) }\end{array}$ & 30 & $30-35$ & $30-35$ & $35-40$ & $35-40$ & $40-45$ & $40-45$ & $45-50$ \\
\hline \multirow[t]{4}{*}{$\begin{array}{l}\text { Intermitten } \\
\text { t aerobics }\end{array}$} & $\begin{array}{l}\text { Treadmill } \\
\text { running }\end{array}$ & $\begin{array}{l}\text { Intensity } \\
\text { (\%MHR) }\end{array}$ & $45-50$ & $50-55$ & $55-60$ & $60-65$ & $65-70$ & $70-75$ & $75-80$ & $75-80$ \\
\hline & & $\begin{array}{c}\text { Duration } \\
\text { (min) }\end{array}$ & $10-12$ & $10-12$ & $12-15$ & $12-15$ & $15-18$ & $15-18$ & $18-20$ & $18-20$ \\
\hline & $\begin{array}{c}\text { Fixed } \\
\text { Bicycle }\end{array}$ & $\begin{array}{c}\text { Intensity } \\
\text { (Watt) }\end{array}$ & 15 & 15 & 20 & 20 & 25 & 25 & 30 & 30 \\
\hline & & $\begin{array}{c}\text { Duration } \\
\text { (min) }\end{array}$ & $10-13$ & $10-13$ & $13-15$ & $13-15$ & $15-17$ & $15-17$ & $17-20$ & $17-20$ \\
\hline
\end{tabular}




\section{RESULTS}

The demographic characteristics of the participants are shown in table 2 .

Intermittent and continuous aerobic exercise decreased the serum levels of hs-CRP and IL-6 and TNF- $\alpha$ in the exercise groups (Table 3).
The level of TNF- $\alpha$ differed significantly between the exercise groups $(\mathrm{P}=0.040)$, but there was no significant difference between serum level of TNF- $\alpha$ between the continuous aerobic exercise group and the control group.

Table 2. Demographic features of the participants

\begin{tabular}{cccc}
\hline Group & $\begin{array}{c}\text { Continuous aerobic } \\
\text { exercise }\end{array}$ & $\begin{array}{c}\text { Intermittent aerobic } \\
\text { exercise }\end{array}$ & Control \\
\hline Variable & $57.07 \pm 3.31$ & $57.21 \pm 3.37$ & $57.85 \pm 2.79$ \\
Age (years) & $172.92 \pm 3.97$ & $171.85 \pm 3.67$ & $171.64 \pm 3.41$ \\
\hline Height $(\mathrm{cm})$ & $83.42 \pm 4.76$ & $83.78 \pm 4.79$ & $84.50 \pm 6.04$ \\
\hline Weight $(\mathrm{kg})$ & $28.01 \pm 1.37$ & $28.38 \pm 1.61$ & $28.68 \pm 1.94$ \\
\hline BMI $\left(\mathrm{kg} / \mathrm{m}^{2}\right)$ & & & \\
\hline
\end{tabular}

Table 3. Inter-group differences of means between the study groups

\begin{tabular}{|c|c|c|c|c|c|c|}
\hline Variable & Group & $\begin{array}{c}\text { Continuous aerobic } \\
\text { mean } \pm \text { ) exercise } \\
\text { (SD }\end{array}$ & $\begin{array}{c}\text { Intermittent } \\
\text { aerobic exercise } \\
(\text { mean } \pm \text { SD) }\end{array}$ & $\begin{array}{c}\text { Control } \\
(\text { mean } \pm \text { SD) }\end{array}$ & $\begin{array}{c}\mathbf{F} \\
\text { Inter- } \\
\text { group }\end{array}$ & P-value \\
\hline hsCRP & Pretest & $2.46 \pm 1.01$ & $245 \pm 0.97$ & $2.44 \pm 1.076$ & \multirow[t]{2}{*}{2.4 .138} & \multirow[t]{2}{*}{0.023} \\
\hline$(\mathrm{mg} / \mathrm{l})$ & post-test & $1.88 \pm 0.92$ & $1.85 \pm 0.85$ & $2.42 \pm 0.68$ & & \\
\hline IL-6 & Pretest & $3.32 \pm 1.06$ & $3.31 \pm 1.32$ & $3.07 \pm 0.94$ & \multirow[t]{2}{*}{4.489} & \multirow[t]{2}{*}{0.018} \\
\hline$(\mathrm{pg} / \mathrm{ml})$ & post-test & $2.84 \pm 1.08$ & $2.81 \pm 1.17$ & $2.90 \pm 0.86$ & & \\
\hline TNF- $\alpha$ & Pretest & $9.10 \pm 0.71$ & $9.09 \pm 0.96$ & $8.92 \pm 0.99$ & \multirow[t]{2}{*}{3.294} & \multirow[t]{2}{*}{0.048} \\
\hline$(\mathrm{pg} / \mathrm{ml})$ & post-test & $8.78 \pm 0.75$ & $8.63 \pm 0.89$ & $8.85 \pm 0.92$ & & \\
\hline
\end{tabular}

\section{DISCUSSION}

Our results showed that aerobic exercises decreased the level of all three parameters. In 2016, Hammond et al. stated that increased physical activity and exercise can reduce hsCRP even in adults with heart disease (19). In 2017, Tenorio et al. investigated the effects of low to high intensity aerobic exercise on inflammatory biomarkers and endothelial dysfunction. The study reported that intermittent exercise can significantly decrease TNF- $\alpha$ level. Although both trainings could partially improve some inflammatory factors, the effects of intermittent exercise were more profound compared to the effects of lowintensity aerobic exercise, which is in line our findings (20). However, Kim et al. did not observe any significant change in IL-6 levels after six weeks of training, which is inconsistent with our findings (21). This difference in the results could be due to differences in the number of participants and duration of exercise program. In line with our findings, Haghir et al. reported that eight weeks of aerobic training significantly decreases CRP levels in heart failure patients (22).In a study by Bijeh and Hejazi, six months of aerobic training slightly decreased CRP levels (23). Recent studies have reported that intense intermittent workouts will have more significant effects on BMI compared to moderate-intensity training. Given that CRP is associated with BMI and fat mass, intermittent exercise and the increased catecholamine concentration can further stimulate lipolysis (24). A common concept regarding the pathophysiological mechanism of atherosclerosis is the production of inflammatory cytokines in response to oxidized low-density lipoprotein (LDL) and macrophages associated with atherosclerotic plaques. . It is thought that regular or longterm exercise can decrease oxidized LDL as well as the levels of IL- 6 and TNF- $\alpha(25,26)$.

This effect may be exerted directly by reduction of cytokine production in fat, muscle and mononuclear cells, and indirectly by 
increasing insulin sensitivity, which improves endothelial function and results in weight loss (27). One of the most important interleukins responsible for lowering CRP levels after exercise is IL-6, which is secreted from adipose cells. Continuous exercise can decrease adipose tissues, thus reducing serum levels of IL-6 and CRP (28). Moreover, IL-6 has pro-inflammatory properties in fat and liver cells and causes insulin resistance. The effect of exercise on IL-6 production is strongly dependent on exercise duration and muscle mass (29). The positive effects of exercise on IL-6 expression may also be related to the increase in lipolysis, lipid oxidation, glycogen homeostasis and antiinflammatory activity. It has been also suggested that aerobic exercise may increase lipolysis by stimulating production of hormones that are sensitive to lipase activity, which may be related to the decrease in TNF- $\alpha$ (30).

\section{CONCLUSION}

The results of this study indicate that eight weeks of continuous and intermittent aerobic exercise can significantly decrease some inflammatory indices in men with heart failure, while the effects of intermittent aerobic exercise was slightly stronger than the effects of continuous aerobic exercise. It is recommended to investigate effects of aerobic exercise with a controlled diet and at various exercise intensities on inflammatory indices of heart failure patients.

\section{ACKNOWLEDGEMENTS}

The authors would like to sincerely thank and appreciate the cooperation of all those who helped us in this study.

\section{CONFLICT OF INTEREST}

The authors declare that there is no conflict of interest.

\section{REFERENCES}

1.Mendis S, Puska P, Norrving B. Global Atlas on Cardiovascular Disease Prevention and Control. World Health Organization. 2011; 12-35.

2. Boettger S, Müller HJ, Oswald K, Puta C, Donath L, Gabriel $\mathrm{HH}$, et al. Inflammatory Changes upon a Single Maximal Exercise Test in Depressed Patients and Healthy Controls. Prog Neuropsychopharmacol Biol Psychiatry. 2010; 34(3): 475-8. doi:10.1016/j. pnpbp. 2010.01.016.

3. Hejazi SM, Hosseni Abrishami L, Mohammad Khani J, Boghrabadi V. The Effect of 8 Week Aerobic Exercises on Serum Levels of Cell Adhesion Molecules among Middle-aged Women. Advanced Studies in Biology. 2013; 5(6): 279-289. doi:10.12988/asb.2013.3210.

4. Van Kimmenade RR, Januzzi JL. Emerging Biomarkers in Heart Failure. Clinical Chemistry. 2012; 58(1): 127-38. doi:10.1373/clinchem.2011.165720.
5. Dowlati Y, Herrmann N, Swardfager W, Liu H, Sham L, Reim EK, et al. Meta-Analysis of Cytokines in Major Depression. Biol Psychiatry. 2010; 67 (5): 446-457. doi:10.1016/j.biopsych.2009.09.033.

6. Csiszar A, Ungvari Z. Synergistic Effects of Vascular IL-17 and TNFalpha may Promote Coronary Artery Disease. Med $\begin{array}{llll}\text { Hypotheses. } & \text { 2004; } & 63(4): & \end{array}$ doi:10.1016/j.mehy.2004.03.009.

7. Satti HS, Hussain S, Javed Q. Association of Interleukin-6 Gene Promoter Polymorphism with Coronary Artery Disease in Pakistani Families. ScientificWorldJournal. 2013; 2013: 538365. doi: 10.1155/2013/538365.

8. Tsimikas S, Duff GW, Berger PB, Rogus J, Huttner K, Clopton $\mathrm{P}$, et al. Pro-Inflammatory Interleukin-1 Genotypes Potentiate the Risk of Coronary Artery Disease and Cardiovascular Events Mediated by Oxidized Phospholipids and Lipoprotein(a). J Am Coll Cardiol. 2014; 63(17): 1724-34. doi:10.1016/j.jacc.2013.12.030.

9. Zgraggen L, Fischer JE, Mischler K, Preckel D, Kudielka BM, Von Känel R. Relationship Between Hemoconcentration and Blood Coagulation Responses to Acute Mental Stress. Thromb Res. 2005; 115(3): 175-83. doi:10.1016/j.thromres.2004.08.022.

10. Signorelli SS, Mazzarino MC, Di Pino L, Malaponte G, Porto C, Pennisi G, et al. High Circulating Levels of Cytokines (IL-6 and TNFalpha), Adhesion Molecules (VCAM-1 and ICAM-1) and Selectins in Patients with Peripheral Arterial Disease at Rest and after a Treadmill Test. Vasc Med. 2003; 8(1): 15-19. doi:10.1191/1358863x03vm466oa.

11. Michowitz Y, Arbel Y, Wexler D, Sheps D, Rogowski O, Shapira I, et al. Predictive Value of High Sensitivity CRP in Patients with Diastolic Heart Failure. Int J of Cardiology. 2008; 125: 347-351. doi:10.1016/j.ijcard.2007.02.037.

12. Wilund KR. Is the Anti-Inflammatory Effect of Regular Exercise Responsible for Reduced Cardiovascular Disease? Clin Sci (Lond). 2007; 112(11): 543-55. doi:10.1042/CS20060368.

13. Witkowska AM. Soluble ICAM-1: A Marker of Vascular Inflammation and Lifestyle. Cytokine. 2005; 31(2): 127-34. doi:10.1016/j.cyto.2005.04.007.

14. Pearson MJ, Mungovan SF, Smart NA. Effect of Aerobic and Resistance Training on Inflammatory Markers in Heart Failure Patients: Systematic Review and Meta-Analysis. Heart Failure Reviews. 2018; 23(2): 209-223. doi:10.1007/s10741018-9677-0.

15. Friedenreich CM, O'Reilly R, Shaw E, Stanczyk FZ, Yasui $\mathrm{Y}$, Brenner DR, et al. Inflammatory Marker Changes in Postmenopausal Women after a Year-Long Exercise Intervention Comparing High Versus Moderate Volumes. Cancer Prevention Research. 2016; 9(2): 196-203. doi:10.1158/1940-6207.CAPR-15-0284.

16. Jakicic JM, Wing RR, Butler BA, Robertson RJ. Prescribing Exercise in Multiple Short Bouts Versus one Continuous Bout: Effects on Adherence, Cardiorespiratory Fitness, and Weight Loss in Overweight Women. Int J Obes Relat Metab Disord. 1995; 19(12): 893-901.

17. Pate RR, Pratt M, Blair SN, Haskell WL, Macera CA, Bouchard C, et al. Physical Activity and Public Health. A Recommendation from the Centers for Disease Control and Prevention and the American College of Sports Medicine. JAMA. 1995; 273(5): 402-7. doi:10.1001/jama.273.5.402.

18. AACVPR. Cardiac Rehabilitation Resource Manual. Chicago, IL. Human Kinetics. 2006; 142-147.

19. Hammonds TL, Gathright EC, Goldstein CM, Penn MS, Hughes JW. Effects of Exercise on C-Reactive Protein in Healthy Patients and in Patients with Heart Disease: A MetaAnalysis. Heart Lung. 2016; 45(3): 273-82. doi:10.1016/j.hrtlng.2016.01.009.

20. Tenorio TRS, Balagopal PB, Andersen LB, Ritti-Dias RM, Hill JO, Lofrano-Prado MC, et al. Effect of Low vs. High Intensity Exercise Training on Biomarkers of Inflammation and Endothelial Dysfunction in Adolescents with Obesity: A 6-Month Randomized Exercise Intervention Study. Pediatr Exerc Sci. 2018; 30(1): 96-105. doi: 10.1123/pes.2017-0067. 
21. Kim ES, Im JA, Kim K, Park H, Suh S, Kang E. Improved Insulin Sensitivity and Adiponectin Level After Exercise Training in Obese Korean Youth. Obesity (Silver Spring). 2007; 15(12): 3023-30. doi: 10.1038/oby.2007.360.

22. Haghir H, Hejazi S M, Minaee S. Changes of Serum Intercellular Adhesion Molecule - 1, Vascular Adhesion Molecule-1 and C-Reactive Protein in Middle-Aged Men with Heart Failure after Eight Weeks of Aerobic Exercise. JSSU. 2017; 24(12): 1013-1023.

23. Bijeh N, Hejazi K. The Effect of Aerobic Exercise on Levels of HS-CRP, Insulin Resistance Index and Lipid Profile in Untrained Middle-aged Women. RJMS. 2018; 24 (163): 1-11.

24. Keating SE, Machan EA, O'Connor HT, Gerofi JA, Sainsbury A, Caterson ID, et al. Continuous Exercise but not High Intensity Interval Training Improves Fat distribution in Overweight Adults. J Obes. 2014; 2014: 834865. doi: 10.1155/2014/834865. DOI:10.1155/2014/834865.

25. Mattusch F, Dufaux B, Heine O, Mertens I, Rost R. Reduction of the Plasma Concentration of C-Reactive Protein Fllowing Nine Months of Endurance Training. Int J sports Med. 2000; 21: 21-24. doi:10.1055/s-2000-8852.
26. Lakka TA, Laaksonen DE. PhysicalAactivity in Prevention and Ttreatment of the Metabolic Syndrome. Appl Physiol Nutr Metab. 2007; 32(1): 76-88. doi:10.1139/h06-113.

27. Nicklas BJ, You T, Pahor M. Behavioural Treatments for Chronic Systemic Inflammation: Effects of Dietary Weight Loss and Exercise Training. CMAJ. 2005; 172(9): 1199-209. doi:10.1503/cmaj.1040769.

28. Leick L, Lindegaard B, Stensvold D, Plomgaard P, Saltin B, Pilegaard H. Adipose Tissue Interleukin-18 mRNA and Plasma Interleukin 18: Effect of Obesity and Exercise. Obesity. 2007; 15(2): 356-63. doi:10.1038/oby.2007.528.

29. Abedi B. The Effects of 12-wk Combined Aerobic/Resistance Ttraining on C-Reactive Protein (CRP) Serum and Interleukin-6 (IL-6) Plasma in Sedentary Men. Yafte. 2012; 14(4): 95-106. [Persian]

30. Balducci S, Zanuso A, Nicolucci F, Fernando S. Cavllo S, Fallucca E, et al. Anti-inflammatory Effect of Exercise Training in Subjects with Type 2 Diabetes and the Metabolic Syndrome is Dependent on Exercise Modalities and Independent of Weight Loss. Nutr METAB Cardiovasc Dis. 2010; 20(8): 608-17. doi:10.1016/j.numecd.2009.04.015.

\section{How to Cite:}

This paper should be cited as: Hejazi SM., Hosseni Abrishami L. [Changes in Some Inflammatory Indices in Men with Heart Failure after Eight Weeks of Continuous and Intermittent Aerobic Exercise]. mljgoums. 2020; 14(5):42-47 . DOI: 10.29252/mlj.14.5.42 